\title{
Trend Analyses of Critical Values Obtained for Minimum Energy Consumption Ratio Achievable in Ubicomp MANETs Using Location-Aware Transmission Strategies.
}

\author{
M. Kaleem GALAMALI, Assoc. Prof Nawaz MOHAMUDALLY
}

\begin{abstract}
Research concerning location-tracking, MANET transmission and location-aware transmission for ubicomp [1-50]. Nevertheless, the fruitful merging of these fields still has a long way ahead. One determinant factor over which such merging will be based is correct protocols design methodologies, which are currently claimed to be heuristic in nature [88] and hence are illsuited for implementation. Refinements are also looked forward to, as concerns middleware services and architecture $[89,90]$.
\end{abstract}

A more advanced objective in this direction of developments is arriving at "realism" in design and evaluation of wireless routing protocols [91]. Such kinds of research will also yield more usable components for predictability in ubicomp. "Realism" is tediously wide scope since it encrusts into each feature related to ubicomp. Such a feature was investigated in a prior paper [19] to assess the trend of Minimum Energy Consumption Ratio (Min_R) recordable for a CBR under different sets of node densities in ubicomp environments. This study was reinforced by the corresponding study of trends for each Min_R parameter of equations [35].

To consolidate realism in knowledge of these trends, in this paper, the next investigation required is framed as: " What are observable critical values in Min_R trends over varying node densities and trends of such critical values?"

Such knowledge will steadily lead to the design of more realistic ubicomp scenarios which are better suited for advanced testing of newly designed middleware components and communication protocols. This paper is a follow-up of previous investigations [1-50].

Key terms: Ubicomp- Ubiquitous Computing, MAUCMobile and Ubiquitous Computing, Min_R- Minimum Energy Consumption Ratio, CBR- Constant Bit Rate, MANET- Mobile Adhoc Network, CV- Critical Value.

M. Kaleem GALAMALI,

University of Technology Mauritius (student)

Mauritius

Assoc. Prof Nawaz Mohamudally

University of Technology Mauritius,

Mauritius

\section{Introduction}

A commendable solution to poor resource availability in ubicomp is use of MANETs in which distribution of energy consumption load is heavily influenced by node density. A past study [19] was aimed at finding the trends observable for metric Min_R for node densities varying between 7 until 56. The model suggested in that paper is the exponential model of the form:

$G(x)=a * \exp (b *(x-0.01))+c$

Following this study, another study [35] was conducted to model mathematically the trends of the three parameters of the equation obtained, with the belief that such results may serve towards better understanding of the evolution and predictability of ubicomp environments. With slowly happening progresses, designers may produce a serious platform of realistic simulation scenarios over which testing tasks for newly built components, including communication protocols and middleware functions are efficiently undertaken.

The type of exploration for metric Min_R now called for is the identification of observable critical values obtained during experimentations and formulation of corresponding theoretical trend of such critical values over varying node densities. Five such critical values were observed.

The key contribution of this paper is the resolving of the trend of variations for each of the five critical values observed for metric Min_R introduced previously [19, 35] covering node numbers 7 until 56. Such information must be rightly presented so as to help ubicomp designers to more valuably understand the evolution and predictability of ubicomp behaviour and prepare more appropriate simulation scenarios with which novel communication protocols could be earnestly tested. The rest of this paper is organised as follows: section 2- Min_R Critical Values, section 3Critical Values Trend Analyses- Metric Min_R, section 4- Conclusion and References.

\section{Min_R Critical Values.}

\subsection{Critical Values Identified.}

Five critical values have been identified as follows: Column headings are: $\mathrm{C} 1 \rightarrow$ Min_R CV, C2 $\rightarrow$ Meaning of Min_R CV, C3 $\rightarrow$ Corresponding figure number for the Min_R CV. 
Proc. of the Seventh International Conference On Advances in Computing, Electronics and Electrical Technology - CEET 2017. Copyright (C) Institute of Research Engineers and Doctors. All rights reserved.

ISBN: 978-1-63248-126-9 doi: 10.15224/ 978-1-63248-126-9-24

\begin{tabular}{|c|l|c|}
\hline C1 & C2 & C3 \\
\hline 1 & \% CBR at modal value of min_ratio. & 1 \\
\hline 2 & Second modal value of min_ratio. & 2 \\
\hline 3 & $\begin{array}{l}\text { \%CBR at second modal value of } \\
\text { min_ratio. }\end{array}$ & 3 \\
\hline 4 & Highest value of min_ratio. & 4 \\
\hline 5 & \% CBR at highest value of min_ratio. & 5 \\
\hline
\end{tabular}

Table 1: Min_R Critical Values

\subsection{Experimental Critical Values Obtained.}

The values obtained during experiments have been summarised below. Values have been rounded to a maximum of 9 decimal places. Column heading $\mathrm{NN} \rightarrow$ Node Number.

\begin{tabular}{|c|c|c|c|c|c|}
\hline & V1 & CV2 & & CV4 & \\
\hline 7 & 84.063492063 & 0.01 & 619047619 & 1.0 & 4.3015873 \\
\hline 8 & & .01 & & .0 & \\
\hline 9 & & 0.01 & & 1.0 & \\
\hline 10 & & 0.01 & & 1.0 & \\
\hline 11 & & 0.01 & 7619 & 1.0 & 794 \\
\hline 12 & 843 & 0.01 & 776 & 1.0 & \\
\hline 13 & & 0.01 & & 1.0 & \\
\hline 14 & 6 & 0.01 & & 1.0 & \\
\hline 15 & 503 & 0.01 & & 1.0 & \\
\hline 16 & & 0.01 & & 1.0 & \\
\hline 17 & 13 & 0.01 & & 1.0 & \\
\hline 18 & & 0.01 & & .0 & \\
\hline 19 & 46 & 0.01 & & 1.0 & \\
\hline 20 & & 0.01 & & 1.0 & \\
\hline 21 & & 0.01 & & 1.0 & \\
\hline 22 & 05 & 0.01 & & 1.0 & \\
\hline 23 & & & & & \\
\hline 24 & 67 & 0.01 & & 1.0 & \\
\hline 25 & 540 & 0.01 & & 1.0 & \\
\hline 26 & & 0.01 & & & \\
\hline 27 & 22 & 0.01 & & 1.0 & \\
\hline 28 & 78 & 0.01 & & 0 & \\
\hline 29 & & 0.01 & & .0 & \\
\hline 30 & 47.5 & 0.01 & 67 & 1.0 & \\
\hline 31 & & 0.01 & & .0 & \\
\hline 32 & 47.1 & 0.01 & & 1.0 & \\
\hline 33 & 47.4 & 0.01 & & .0 & \\
\hline 34 & 47.38 & 0.01 & & 1.0 & \\
\hline 35 & 47.206349206 & 0.01 & 349 & 1.0 & 952 \\
\hline 36 & 46.71 & 0.01 & 0794 & 1.0 & 3175 \\
\hline 37 & 47.45 & 0.01 & & 1.0 & \\
\hline 38 & 47.380 & 0.01 & 921 & 1.0 & 587 \\
\hline 39 & 47.44 & 0.01 & & 1.0 & \\
\hline 40 & 47.365079365 & 0.01 & & 1.0 & \\
\hline 41 & 47.349206349 & 0.01 & & 1.0 & 428571 \\
\hline 42 & & 0.01 & & 1.0 & \\
\hline 43 & 47.222222222 & 0.01 & 365079 & 1.0 & 20635 \\
\hline 44 & 47.585 & 0.01 & 929 & 1.0 & 8412 \\
\hline 45 & 47.190476190 & 0.01 & & 1.0 & 4.714285714 \\
\hline 46 & 47.206 & 0.01 & & 1.0 & 4.936507937 \\
\hline 47 & 46.841269841 & 0.01 & & 1.0 & 4.777777778 \\
\hline 48 & 46.619047619 & 0.01 & & 1.0 & 4.730158730 \\
\hline 49 & 46.476190476 & 0.01 & 5.936507937 & 1.0 & 4.555555556 \\
\hline
\end{tabular}

\begin{tabular}{l|l|l|l|l|l|l|l|}
50 & 45.873015873 & 0.01 & 5.730158730 & 1.0 & 5.539682540 \\
\hline
\end{tabular} \begin{tabular}{|l|l|l|l|l|l|}
51 & 45.666666667 & 0.01 & 5.539682540 & 1.0 & 5.714285714 \\
\hline
\end{tabular} \begin{tabular}{|l|l|l|l|l|l|}
\hline 52 & 45.460317460 & 0.01 & 5.6666666667 & 1.0 & 5.603174603 \\
\hline
\end{tabular} \begin{tabular}{|c|c|c|c|c|c|c|}
\hline 53 & 45.333333333 & 0.01 & 5.666666667 & 1.0 & 5.603174603 \\
\hline
\end{tabular} \begin{tabular}{|l|l|l|l|l|l|}
\hline 54 & 45.444444444 & 0.01 & 5.555555556 & 1.0 & 5.825396825 \\
\hline
\end{tabular} \begin{tabular}{|l|l|l|l|l|l|}
\hline 55 & 45.650793651 & 0.01 & 5.365079365 & 1.0 & 5.682539683 \\
\hline
\end{tabular} \begin{tabular}{|l|l|l|l|l|l|l|}
56 & 45.492063492 & 0.01 & 5.476190476 & 1.0 & 5.666666667
\end{tabular}

Table 2: Experimental Critical Values Obtained

\section{Critical Values Trend Analyses- Metric Min_R.}

\subsection{General Procedure Adopted.}

The tabulated data for each Min_R CV is plotted on gnuplot over Linux. Graphical analyses using the "Fit" command has been undertaken here. Assistance from smooth bezier plot has also been sought. For each graph of critical value obtained, the general observations are reported. Here also, various equations of fit are attempted and their corresponding summary report is detailed hereunder, for each Min_R critical value. Concludingly, for two critical values choice of best fit is made based on flat values and for the remaining three critical values, choice is based on least reduced chi-square and most acceptable extendability produced at node numbers 80,100 and 120. Lastly, the values of parameters for each equation corresponding to Min_R critical value, is recorded.

\subsection{Trend Analysis - Min R CV1.}

Generally, a decreasing tendency at a decreasing rate is observed here. A minor oscillation is also noticed but its amplitude is very small and hence is ignored.

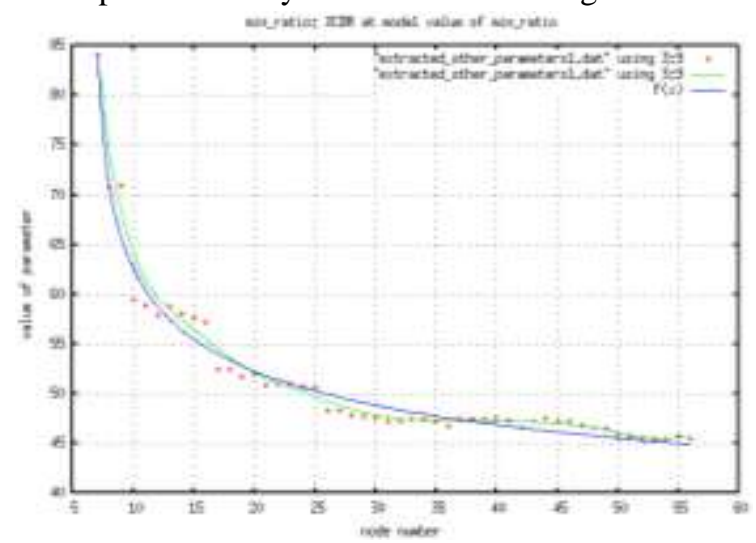

Figure 1: Min_R Critical Value 1

The potentially applicable equations are:

$$
\begin{array}{ll}
\text { 1. } F(x)=a /(\log ((\mathrm{b} * \mathrm{x})+\mathrm{c})+\mathrm{d}) \\
\text { Ch_sq }=1.86906 & \mathrm{~F}(80)=42.994567769 \\
\mathrm{~F}(100)=41.934947393 & \mathrm{~F}(120)=41.118380377 \\
\text { 2. } \mathrm{F}(\mathrm{x})=(\mathrm{a} \star \mathrm{x}) /(\log & ((\mathrm{b} * \mathrm{x})+\mathrm{c})+\mathrm{d}) \\
\text { Ch_sq }=1.96709 & \mathrm{~F}(80)=46.266826802 \\
\mathrm{~F}(100)=46.530344023 & \mathrm{~F}(120)=46.921809576
\end{array}
$$


Proc. of the Seventh International Conference On Advances in Computing, Electronics and Electrical Technology - CEET 2017. Copyright ( ) Institute of Research Engineers and Doctors. All rights reserved. ISBN: 978-1-63248-126-9 doi: 10.15224/ 978-1-63248-126-9-24

$$
\begin{aligned}
& \text { 3. } F(x)=\left(a * x^{0.5}\right) /(\log ((b * x)+c)+d) \\
& \text { Ch_sq }=2.30177 \quad \mathrm{~F}(80)=47.311596421 \\
& \mathrm{~F}(100)=48.240209958 \quad \mathrm{~F}(120)=49.246003693 \\
& \text { 4. } F(x)=\left(a * x^{0.25}\right) /(\log ((b * x)+c)+d) \\
& \text { Ch_sq }=1.88506 \quad \mathrm{~F}(80)=45.721158561 \\
& \mathrm{~F}(100)=45.723177847 \quad \mathrm{~F}(120)=45.834505107
\end{aligned}
$$

\section{Choice of best fit for Min_R Critical Value 1}

The equation in part 1 above has been selected because of smallest ch_sq and good extendability. The parameters obtained for best fit are:

$\mathrm{a}=408.529, \mathrm{~b}=3.40018, \mathrm{c}=-21.4209, \mathrm{~d}=3.97804$

\subsection{Trend Analysis - Min_R CV2.}

For all node numbers, the value of this critical value remains at 0.01 .

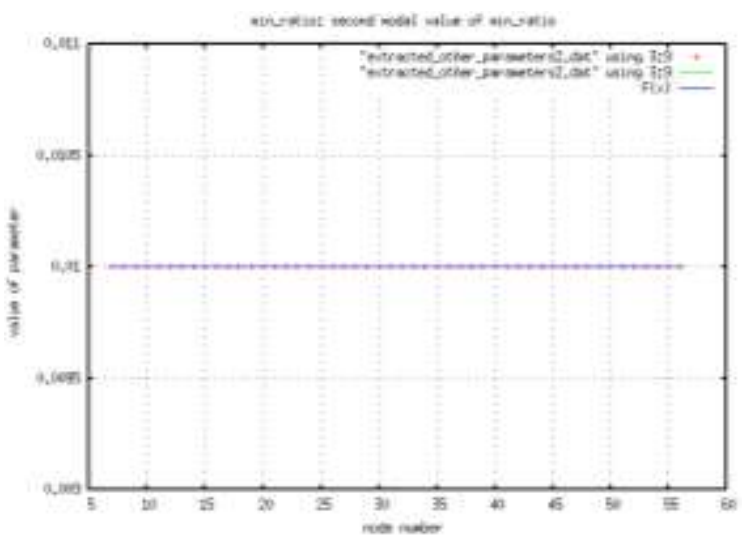

Figure 2: Min_R Critical Value 2

$$
F(x)=0.01
$$

It is expected that for higher node numbers, the same value will apply.

\subsection{Trend Analysis - Min_R CV3.}

The curve obtained depicts an initial rapid increase until a maximum point is reached and then a slow decrease in value with an oscillation is obtained.

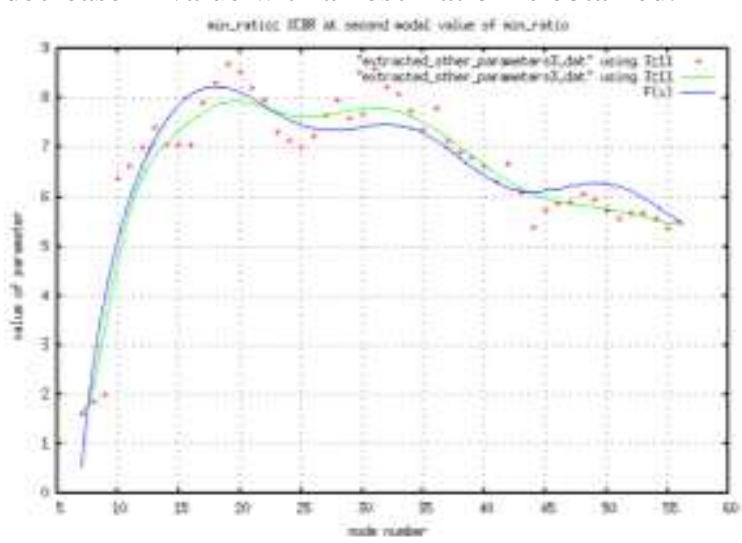

Figure 3: Min_R Critical Value 3

This section has been tackled in two parts:

i. Find equation of best fit for axis of oscillation.

ii. Find equation of best fit for oscillation along axis.
Step1: Find equation of best fit for axis of oscillation

$$
\begin{array}{rl}
\text { 1. } F(x)=\left(a * x^{-1}+f\right) /(\log \quad((b * x)+c)+d) \\
\text { Ch_sq }=0.426389 & F(80)=4.604813948 \\
F(100)=4.028292838 & F(120)=3.604506387 \\
\text { 2. } F(x)=\left(a * x^{-0.75}+f\right) /(\log \quad((b * x)+c)+d) \\
\text { Ch_sq }=0.430509 & F(80)=4.674689825 \\
F(100)=4.120362246 & F(120)=3.712748938 \\
\text { 3. } F(x)=\left(a * x^{-1.25}+f\right) /(\log \quad((b * x)+c)+d) \\
\text { Ch_sq }=0.430909 & F(80)=4.599209573 \\
F(100)=4.016100995 & F(120)=3.586184668
\end{array}
$$

\section{Choice of best fit for axis of oscillation}

The equation in part 1 above has been selected because of smallest reduced chi-square value.

Step 2: Finding equation of best fit for oscillation $F(x)=\left(a * x^{-1}+f\right) /(\log ((b * x)+c)+d)+$ $g * \sin ((h * x)+i)$

$$
\begin{array}{ll}
\text { Ch_sq }=0.4076 & \mathrm{~F}(80)=4.633986446 \\
\mathrm{~F}(100)=4.333108740 & \mathrm{~F}(120)=3.767992263
\end{array}
$$

The parameters of fit are: $a=-16.0337, b=84.3975$, $\mathrm{c}=84.3975, \mathrm{~d}=-5.04113, \mathrm{f}=2.38994, \mathrm{~g}=-0.307$ $226, \mathrm{~h}=0.377039, \mathrm{i}=10.7733$

Here, definitely, oscillation in the equation yield better predictability.

\subsection{Trend Analysis - Min_R CV4.}

Here, the critical value stays at 1.0 throughout.

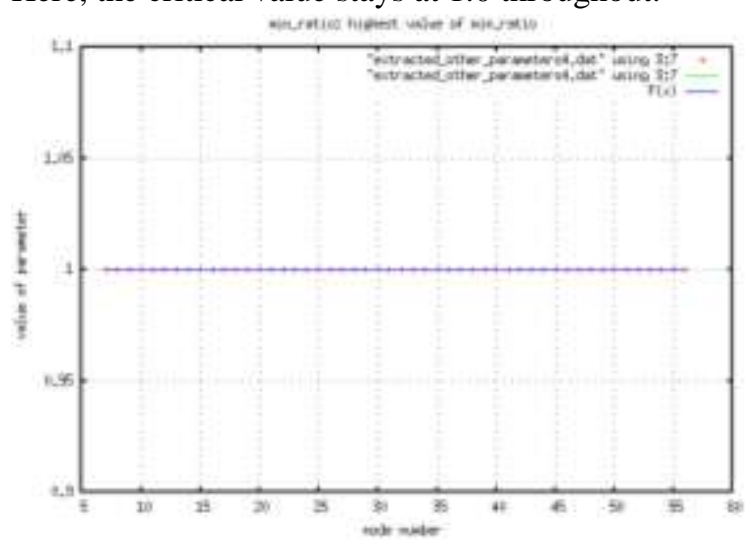

Figure 4: Min_R Critical Value 4

$$
F(x)=1.0
$$

Projected value for higher node numbers will be at 1.0 also.

\subsection{Trend Analysis - Min_R CV5.}

Generally, the curve depicts a decreasing tendency until a minimum point and then shows an increasing tendency. This trend is assumed to be about half a wave to form an oscillation.

$$
\begin{array}{cl}
F(x)=a * \sin ((b * x)-c)+d \\
\text { Ch_sq }=0.215242 & F(80)=6.068855419 \\
F(100)=4.726046609 & F(120)=5.813683947
\end{array}
$$


The parameters of fit are: $a=0.871105, b=0.099$

$8514, \mathrm{c}=-0.848875, \mathrm{~d}=5.58581$

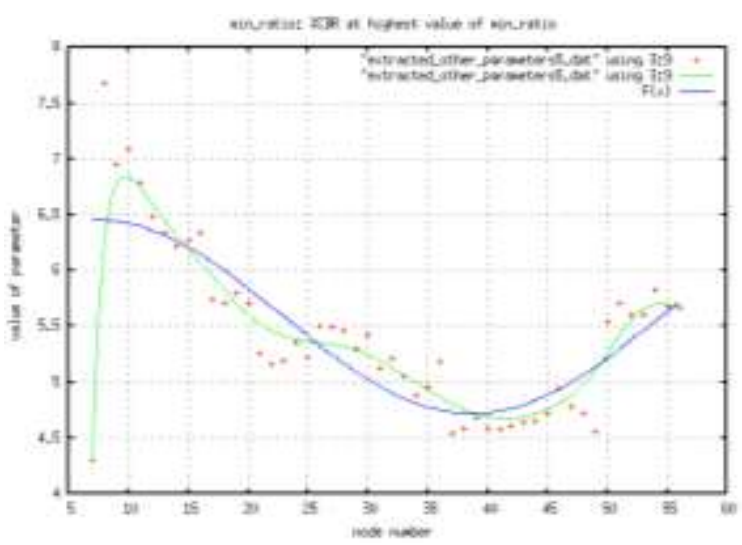

Figure 5: Min_R Critical Value 5

\section{Conclusion.}

This piece of study was targeted at identifying some critical values proper to metric Min_R and study their corresponding trends over varying node densities in a MANET topography of $300 \times 300 \mathrm{~m}^{2}$. The models successful detailed here are of varying complexity of mathematical nature. These output will help in studying MANETs for MAUC environment viewed from software engineering. Such mathematical models can objectively be implemented in computational algorithms to produce more realistic simulation schemes befitting which, novel communication protocols and middleware components produced for ubicomp may be rigorously tested.

The experiments were executed in NS-2 over Linux. The plottings and "Fit" attempts were conducted in gnuplot. Best fit was selected based on flat values for two critical values and on a combination of least reduced chi-square values and best extendability of equations observed at higher node numbers. Assumptions put down in past papers [19, 35] are inherited in this paper also.

This work dwells as a follow-up of previous work [1$13,19,35]$ and remains prone for future upgrades. One such further work identified is the formulation of predictability for metric Min_R and its trend.

\section{References}

[1] M. Kaleem GALAMALI, Assoc. Prof Nawaz MOHAMUDALLY, Towards Dependable Pervasive Systems-A Position and Vision Paper, CEET 2014

[2] M. Kaleem GALAMALI, Assoc. Prof Nawaz MOHAMUDALLY, Model of Energy Savings achievable with Location-aware Node-to-Node Transmission in UbiComp , CEET 2014

[3] M. Kaleem GALAMALI, Assoc. Prof Nawaz
MOHAMUDALLY, Model of Energy Savings achievable with Location-aware Node-to-Node Transmission in UbiComp Using Location Refresh Intervals, CEET 2014

[4] M. Kaleem GALAMALI, Assoc. Prof Nawaz MOHAMUDALLY, Model of Energy Savings achievable with Location-aware Transmission in UbiComp Using Relays, CEET 2014

[5] M. Kaleem GALAMALI, Assoc. Prof Nawaz MOHAMUDALLY, Mathematical modeling of need of exact number of relays to ensure seamless mobility in mobile computing, CEET 2014

[6] M. Kaleem GALAMALI, Assoc. Prof Nawaz MOHAMUDALLY, Modelling of need for multiple relays for ensuring seamless mobility, CEET 2014

[7] M. Kaleem GALAMALI, Assoc. Prof Nawaz MOHAMUDALLY, Investigation of prominence of placements of relays in a ubicomp topography,

[8] M. Kaleem GALAMALI, Assoc. Prof Nawaz MOHAMUDALLY, Model of energy savings achievable with location-aware transmission in ubicomp using optimised number of relays.

[9] M. Kaleem GALAMALI, Assoc. Prof Nawaz MOHAMUDALLY, Investigation of Prominence of Placements of Optimised Number of Relays in a Ubicomp Topography using Location-Aware Transmission, CEET 2015.

[10] M. Kaleem GALAMALI, Assoc. Prof Nawaz MOHAMUDALLY, Extending Node Battery Availability in Ubicomp with Location-Aware Transmission, CEET 2015.

[11] M. Kaleem GALAMALI, Assoc. Prof Nawaz MOHAMUDALLY, Extending Node Battery Availability in Ubicomp with Location-Aware Transmission using Location Refresh Intervals, CEET 2015.

[12] M. Kaleem GALAMALI, Assoc. Prof Nawaz MOHAMUDALLY, Extending Node Battery Availability in Ubicomp with Location-Aware Transmission using Uniformly Placed Relays, CEET 2015.

[13] M. Kaleem GALAMALI, Assoc. Prof Nawaz MOHAMUDALLY, Extending Node Battery Availability in Ubicomp with Location-Aware Transmission Using Optimally Placed Relays, CEET 2015.

[14] M. Kaleem GALAMALI, Assoc. Prof Nawaz MOHAMUDALLY, Model of Sender Node Energy Savings Achievable with Location-Aware MANET Transmission in Ubicomp. ACCN 2016

[15] M. Kaleem GALAMALI, Assoc. Prof Nawaz MOHAMUDALLY, Model of Overall Node Energy Savings Achievable with Location-Aware MANET Transmission in Ubicomp. ACCN 2016

[16] M. Kaleem GALAMALI, Assoc. Prof Nawaz MOHAMUDALLY, Model of Sender Node Extra Energy Savings Achievable in MANET Against Direct Node-toNode Transmission Using Location-Aware Transmission in Ubicomp. ACCN 2016

[17] M. Kaleem GALAMALI, Assoc. Prof Nawaz MOHAMUDALLY, Model of Overall Node Extra Energy Savings Achievable in MANET against Direct Node-toNode Transmission Using Location-Aware Transmission in Ubicomp. ACCN 2016

[18] M. Kaleem GALAMALI, Assoc. Prof Nawaz MOHAMUDALLY, Model of Energy Consumption Ratio Achievable in MANET Using Location-Aware Transmission in Ubicomp. ACCN 2016

[19] M. Kaleem GALAMALI, Assoc. Prof Nawaz MOHAMUDALLY, Model of Minimum Energy Consumption Ratio Achievable in MANET Using LocationAware Transmission in Ubicomp. ACCN 2016

[20] M. Kaleem GALAMALI, Assoc. Prof Nawaz MOHAMUDALLY, Model of Maximum Energy Consumption Ratio Achievable in MANET Using LocationAware Transmission in Ubicomp. ACCN 2016

[21] M. Kaleem GALAMALI, Assoc. Prof Nawaz

MOHAMUDALLY, Model of Overall Energy Consumption Fairness Ratio Achievable in MANET Using LocationAware Transmission in Ubicomp. ACCN 2016

[22] M. Kaleem GALAMALI, Assoc. Prof Nawaz MOHAMUDALLY, Model of Overall Energy Consumption 
Fairness Proportion Achievable in MANET Using LocationAware Transmission for Ubicomp, CEET 2016

[23] M. Kaleem GALAMALI, Assoc. Prof Nawaz MOHAMUDALLY, Model of Minimum Fairness Proportion Achievable in MANET Using Location-Aware Transmission for Ubicomp, CEET 2016

[24] M. Kaleem GALAMALI, Assoc. Prof Nawaz MOHAMUDALLY, Model of Maximum Fairness Proportion Achievable in MANET Using Location-Aware Transmission for Ubicomp, CEET 2016

[25] M. Kaleem GALAMALI, Assoc. Prof Nawaz MOHAMUDALLY, Model of Sender Fairness Proportion Achievable in MANET Using Location-Aware Transmission for Ubicomp, CEET 2016

[26] M. Kaleem GALAMALI, Assoc. Prof Nawaz MOHAMUDALLY, Model of Distance Travelled by packets in MANETs using Location-Aware Transmission for Ubicomp, CEET 2016

[27] M. Kaleem GALAMALI, Assoc. Prof Nawaz MOHAMUDALLY, Model of Maximum CBR Distance Travelled by packets in MANETs using Location-Aware Transmission for Ubicomp, CEET 2016

[28] M. Kaleem GALAMALI, Assoc. Prof Nawaz MOHAMUDALLY, Model of Minimum CBR Distance Travelled by packets in MANETs using Location-Aware Transmission for Ubicomp, CEET 2016

[29] M. Kaleem GALAMALI, Assoc. Prof Nawaz MOHAMUDALLY, Model of Range CBR Distance Experienced by Transmissions in MANETs using LocationAware Transmission for Ubicomp, CEET 2016

[30] M. Kaleem GALAMALI, Assoc. Prof Nawaz MOHAMUDALLY, Trend Analyses of Parameters of Equations for Sender Node Energy Savings Achievable in ubicomp MANETs using Location-Aware Transmission, ACCN 2017.

[31] M. Kaleem GALAMALI, Assoc. Prof Nawaz MOHAMUDALLY, Trend Analyses of Parameters of Equations for Overall Node Energy Savings Achievable in ubicomp MANETs using Location-Aware Transmission, ACCN 2017.

[32] M. Kaleem GALAMALI, Assoc. Prof Nawaz MOHAMUDALLY, Trend Analyses of Parameters of Equations for Sender Node Extra Energy Savings Achievable in MANET against Direct Node-to-Node Location-Aware Transmission, ACCN 2017.

[33] M. Kaleem GALAMALI, Assoc. Prof Nawaz MOHAMUDALLY, Trend Analyses of Parameters of Equations for Overall Nodes Extra Energy Savings Achievable in MANET against Direct Node-to-Node Location-Aware Transmission, ACCN 2017.

[34] M. Kaleem GALAMALI, Assoc. Prof Nawaz MOHAMUDALLY, Trend Analyses of Parameters of Equations for Energy Consumption Ratio Achievable in Ubicomp MANET Using Location-Aware Transmission, ACCN 2017.

[35] M. Kaleem GALAMALI, Assoc. Prof Nawaz MOHAMUDALLY, Trend Analyses of Parameters of Equations for Minimum Energy Consumption Ratio Achievable in Ubicomp MANETs Using Location-Aware Transmission, ACCN 2017.

[36] M. Kaleem GALAMALI, Assoc. Prof Nawaz MOHAMUDALLY, Trend Analyses of Parameters of Equations for Maximum Energy Consumption Ratio Achievable in Ubicomp MANETs Using Location-Aware Transmission, ACCN 2017.

[37] M. Kaleem GALAMALI, Assoc. Prof Nawaz MOHAMUDALLY, Trend Analyses of Parameters of Equations for Overall Fairness Ratio Achievable in Ubicomp MANETs Using Location-Aware Transmission, ACCN 2017.

[38] M. Kaleem GALAMALI, Assoc. Prof Nawaz MOHAMUDALLY, Trend Analyses of Parameters of Equations for Energy Consumption Fairness Proportion Achievable in Ubicomp MANETs Using Location-Aware Transmission, CEET 2017

[39] M. Kaleem GALAMALI, Assoc. Prof Nawaz MOHAMUDALLY, Trend Analyses of Parameters of Equations for Minimum Fairness Proportion Achievable in Ubicomp MANETs Using Location-Aware Transmission, CEET 2017
[40] M. Kaleem GALAMALI, Assoc. Prof Nawaz MOHAMUDALLY, Trend Analyses of Parameters of Equations for Maximum Fairness Proportion Achievable in Ubicomp MANETs Using Location-Aware Transmission, CEET 2017

[41] M. Kaleem GALAMALI, Assoc. Prof Nawaz MOHAMUDALLY, Trend Analyses of Parameters of Equations for Sender Fairness Proportion Achievable in Ubicomp MANETs Using Location-Aware Transmission, CEET 2017

[42] M. Kaleem GALAMALI, Assoc. Prof Nawaz MOHAMUDALLY, Trend Analyses of Parameters of Equations for Packets Per Distance Achievable in Ubicomp MANETs Using Location-Aware Transmission, CEET 2017

[43] M. Kaleem GALAMALI, Assoc. Prof Nawaz MOHAMUDALLY, Trend Analyses of Parameters of Equations for Maximum CBR Distance Achievable in Ubicomp MANETs Using Location-Aware Transmission, CEET 2017

[44] M. Kaleem GALAMALI, Assoc. Prof Nawaz MOHAMUDALLY, Trend Analyses of Parameters of Equations for Minimum CBR Distance Achievable in Ubicomp MANETs Using Location-Aware Transmission, CEET 2017

[45] M. Kaleem GALAMALI, Assoc. Prof Nawaz MOHAMUDALLY, Trend Analyses of Parameters of Equations for Range CBR Distance Achievable in Ubicomp MANETs Using Location-Aware Transmission, CEET 2017

[46] M. Kaleem GALAMALI, Assoc. Prof Nawaz MOHAMUDALLY, Trend Analyses of Critical Values Obtained for Sender Node Energy Savings Achievable in Ubicomp MANETs Using Location-Aware Transmission, CEET 2017

[47] M. Kaleem GALAMALI, Assoc. Prof Nawaz MOHAMUDALLY, Trend Analyses of Critical Values Obtained for Overall Node Energy Savings Achievable in Ubicomp MANETs Using Location-Aware Transmission, CEET 2017

[48] M. Kaleem GALAMALI, Assoc. Prof Nawaz MOHAMUDALLY, Trend Analyses of Critical Values Obtained for Sender Node Extra Energy Savings Achievable in Ubicomp MANET Against Direct Node-to-Node Location-Aware Transmission, CEET 2017

[49] M Kaleem GALAMALI, Assoc. Prof Nawaz MOHAMUDALLY, Trend Analyses of Critical Values Obtained for Overall Nodes Extra Energy Savings Achievable in Ubicomp MANET Against Direct Node-toNode Location-Aware Transmission, CEET 2017

[50] M. Kaleem GALAMALI, Assoc. Prof Nawaz MOHAMUDALLY, Trend Analyses of Critical Values Obtained for Energy Consumption Ratio Achievable in Ubicomp MANETs Using Location-Aware Transmission Strategies, CEET 2017

[51] Markus Bylund and Zary Segall, Towards seamless mobility with personal servers, 2004

[52] Masugi Inoue, Mikio Hasegawa, Nobuo Ryoki and Hiroyuki Morikawa, Context-Based Seamless Network and Application Control, 2004

[53] Xiang Song, Umakishore Ramachandran, MobiGo: A Middleware for Seamless Mobility, College of Computing Georgia Institute of Technology, Atlanta, GA, USA, August 2007

[54] Budzisz, Ferrús, R., Brunstrom A., Grinnemo, K, Fracchia R., Galante, G., and Casadevall, F. Towards transport-layer mobility: Evolution of SCTP multihoming, March 2008

[55] Paul Dourish \& Genevieve Bell, Divining a digital future, 2011.

[56] Xiang Song, Seamless Mobility In Ubiquitous Computing Environments, PhD Thesis, Georgia Institute of Technology, August 2008

[57] Kevin O Mahony, Jian Liang, Kieran Delaney, User-Centric Personalization and Autonomous Reconfiguration Across Ubiquitous Computing Environments, NIMBUS Centre Cork Institute of Technology, Cork, Ireland, UBICOMM 2012

[58] Pablo Vidales, Seamless mobility in 4G systems, Technical Report, University of Cambridge, Computer Laboratory, Number 656, November 2005

[59] João Pedro Sousa and David Garlan, Aura: An Architectural Framework for User Mobility in Ubiquitous Computing 
Proc. of the Seventh International Conference On Advances in Computing, Electronics and Electrical Technology - CEET 2017. Copyright ( ) Institute of Research Engineers and Doctors. All rights reserved.

ISBN: 978-1-63248-126-9 doi: 10.15224/ 978-1-63248-126-9-24

Environments, School of Computer Science, Carnegie Mellon University, USA, August 2002

[60] Dennis Lupiana, Ciaran O'Driscoll, Fredrick Mtenzi, Defining Smart Space in the Context of Ubiquitous Computing, Dublin Institute of Technology, Ireland, Special Issue on ICIT 2009 Conference - Web and Agent Systems, 2009

[61] N.S.V.Shet1, Prof.K.Chandrasekaran2 and Prof. K.C.Shet3, WAP Based Seamless Roaming In Urban Environment with Wise Handoff Technique, International Journal of UbiComp (IJU), Vol.1, No.4, October 2010

[62] Yipeng Yu Dan He Weidong Hua Shijian Li Yu Qi Yueming Wang Gang Pan, FlyingBuddy2: A Braincontrolled Assistant for the Handicapped, Zhejiang University, UbiComp'12, September 5-8, 2012.

[63] Jing Su, James Scott, Pan Hui, Jon Crowcroft, Eyal de Lara Christophe Diot, Ashvin Goel, Meng How Lim, and Eben Upton, Haggle: Seamless Networking for Mobile Applications, 2007

[64] Rui Han, Moustafa M. Ghanem, Li Guo, Yike Guo*, Michelle Osmond, Enabling cost-aware and adaptive elasticity of multi-tier cloud applications, Future Generation Computer Systems, 2012

[65] Byrav Ramamurthy, K. K. Ramakrishnan, Rakesh K. Sinha, Cost and Reliability Considerations in Designing the NextGeneration IP over WDM Backbone Networks, 2012.

[66] Bhavish Aggarwal, Aditya Akella, Ashok Anand, Athula Balachandran, Pushkar Chitnis, Chitra Muthukrishnan, Ram Ramjee and George Varghese, EndRE: An End-System Redundancy Elimination Service for Enterprises, NSDI 2010, San Jose, CA

[67] Ashok Anand, Vyas Sekar and Aditya Akella, SmartRE: An Architecture for Coordinated Network-wide Redundancy Elimination, SIGCOMM 2009, Barcelona, Spain

[68] John Breeden II, "Smart-phone battery life could double without better batteries", Nov 14, 2012

[69] Andy Boxall, "When will your phone battery last as long as your kindle", December 5, 2012.

[70] Imielinski, T. and Navas, J.C. (1999). GPS-based geographic addressing, routing, and resource discovery. Comms. ACM, Vol. 42, No. 4, pp. 86-92.

[71] Hightower, J. and Borriello, G. (2001). Location Systems for Ubiquitous Computing. IEEE Computer, Vol. 34, No. 8, August, pp. 57-66.

[72] Harter, A., Hopper, A., Steggles, P., Ward, A. and Webster, P. (2002). The Anatomy of a Context-Aware Application. Wireless Networks, Vol. 8, No. 2-3, Mar-May, pp. 187-197.

[73] Hightower, J., Brumitt, B. and Borriello, G. (2002). The Location Stack: A Layered Model for Location in Ubiquitous Computing. Proceedings of the 4th IEEE Workshop on Mobile Computing Systems \& Applications (WMCSA 2002), Callicoon, NY, USA, June, pp. 22-28.

[74] Graumann, D., Lara, W., Hightower, J. and Borriello, G. (2003). Real-world implementation of the Location Stack: The Universal Location Framework. Proceedings of the 5th IEEE Workshop on Mobile Computing Systems \& Applications (WMCSA 2003), Monterey, CA, USA, October, pp. 122-128.

[75] Ko, Y., \& Vaidya, N. H. (2000). Location-aided routing (LAR) in mobile ad hoc networks. Wireless Networks, 6(4), 307-321.

[76] Liao, W.-H., Tseng, Y.-C., \& Sheu, J.-P. (2001). GRID: a fully location-aware routing protocol for mobile ad hoc networks. Telecommunication Systems, 18(1), 37-60.

[77] Kuhn, F., Wattenhofer, R., Zhang, Y., \& Zollinger, A. (2003). Geometric ad-hoc routing: of theory and practice. In Proceedings of the ACM (PODC'03) (pp. 63-72).

[78] Jiang, X., \& Camp, T. (2002). Review of geocasting protocols for a mobile ad hoc network. In Proceedings of the Grace Hopper Celebration (GHC).

[79] Ko, Y. \& Vaidya, N. H. (1999). Geocasting in mobile ad hoc networks: location-based multicast algorithms. In Proceedings of the IEEE (WMCSA '99) (pp. 101).
[80] Mauve, M., Fuler, H., Widmer, J., \& Lang, T. (2003). Position-based multicast routing for mobile ad-hoc networks (Technical Report TR-03-004). Department of Computer Science, University of Mannheim.

[81] Xu, Y., Heidemann, J., \& Estrin, D. (2001). Geographyinformed energy conservation for adhoc routing. In Proceedings of the ACM/IEEE (MOBICOM'01) (pp. 70-84).

[82] Hu, Y.-C., Perrig, A., \& Johnson, D. (2003). Packet leashes: a defense against wormhole attacks in wireless ad hoc networks. In Proceedings of the INFOCOM' 03 (pp. 19761986).

[83] Patwari, N., Hero III, A. O., Perkins, M., Correal, N. S., \& O’Dea, R. J. (2003). Relative location estimation in wireless sensor networks. IEEE Transactions on Signal Processing, 51(8), 2137-2148.

[84] Baldauf, M., Dustdar, S., \& Rosenberg, F. (2007). A Survey on Context Aware Systems. International Journal of Ad Hoc and Ubiquitous Computing, Inderscience Publishers. forthcoming. Pre-print from: http://www.vitalab.tuwien.ac.at/ florian/papers/ijahuc2007.pdf

[85] Hong, D., Chiu, D.K.W., \& Shen, V.Y. (2005). Requirements elicitation for the design of context-aware applications in a ubiquitous environment. In Proceedings of ICEC'05 (pp. 590-596).

[86] Neeraj Tantubay, Dinesh Ratan Gautam and Mukesh Kumar Dhariwal, A Review of Power Conservation in Wireless Mobile Ad hoc Network (MANET)", International Journal of computer Science Issues, Vol 8, Issue 4, No 1, July 2011.

[87] Wenrui Zhao, Mostafa Ammar and Ellen Zegura, “A Message Ferrying Approach for Data Delivery in Sparse Mobile Ad Hoc Networks", MobiHoc'04, May 24-26, 2004, Roppongi, Japan.

[88] Sgroi et al., "Designing Wireless Protocols: Methodology and Applications, February 2000.

[89] Gyula et al., "Simulation-based optimization of communication protocols for large-scale wireless sensor networks", 10 October 2002

[90] Rao and Sharma, "Cross Layer Protocols For Multimedia Transmission in Wireless Networks", June 2012

[91] Herms et al, "Realism in Design and Evaluation of Wireless Routing Protocols", 2007.

About Author (s):

Associate Professor Nawaz Mohamudally works at University of Technology, Mauritius (UTM) and has undertaken supervision of MPhil/PhD Students for many years.

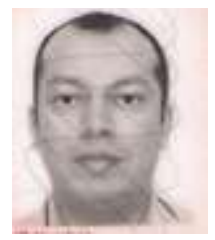

M. Kaleem Galamali is a part-time student (achieved M Phil Transfer on 28.10.2014, currently $\mathrm{PhD}$ student) at UTM under supervision of A.P. Nawaz Mohamudally. 